\title{
Early Modern Swedish Law and Privacy: A Legal Right in Embryo
}

\author{
Mia Korpiola
}

\section{1 \\ Introduction}

In the English language, seclusion, being apart from company or observation, is the oldest and primary meaning of the medieval word 'privacy', also synonymous with private life, solitude, integrity, concealment, and secrecy. ${ }^{1}$ Accordingly, privacy has been defined as the "voluntary and temporal withdrawal of a person from the general society through physical or psychological means.' ${ }^{2}$ It has also been described as 'a social ritual by means of which an individual's moral title to his existence is conferred'. 3

Carried into the legal field, the right to privacy has come to consist of three 'related but interdependent components' in modern law: secrecy, anonymity, and solitude. ${ }^{4}$ Due to its conceptual vagueness and incoherence, privacy has been called 'a residual right' in law. ${ }^{5}$ Ronald Huebert's definition of privacy as 'the condition in which other people are deprived of access to either information about or some experience of [a person] to the extent that [this person decides] to exercise control of access' comes close to these legal components. ${ }^{6}$ Consequently, the legal privacy expert Alan F. Westin has defined it as 'the claim of individuals, groups, or institutions to determine for themselves when, how and to what extent information of them is communicated to others.' ${ }^{7}$

As a legal term and a human right, privacy is neither medieval nor early modern. Almost unmentioned by eighteenth-century Enlightenment thinkers,

1 E.g. Webb D., Privacy and Solitude in the Middle Ages (London - New York: 2007) viii, xv-xvi; Huebert R., Privacy in the Age of Shakespeare (Toronto - Buffalo - London: 2016) 17-24.

2 Meyer Spacks P., Privacy: Concealing the Eighteenth-Century Self(Chicago - London: 2003) 21.

3 Reiman J.H., "Privacy, Intimacy, and Personhood", Philosophy \& Public Affairs 6.1 (1976) 26-44, here 39 .

4 Wacks R., Personal Information: Privacy and the Law (Oxford: 1989) 15-16.

5 Clapham A., Human Rights: A Very Short Introduction (Oxford: 2007) 92. Also Wacks, Personal Information 18-19.

6 Huebert, Privacy 16.

7 Quoted in Meyer Spacks, Privacy 21.

(C) MIA KORPIOLA, 2022 | DOI:10.1163/9789004153073_007

This is an open access chapter distributed under the terms of the CC BY-NC-ND 4.o licensenserpio la - 9789004153073 
it emerged as a special legal category, a legal interest protected by enforceable rights, only in the nineteenth century. ${ }^{8}$ In fact, our present notions of privacy are influenced by liberalism, which perceives 'privacy as a set of rights forming a protective bubble around every individual', guaranteeing them a safeguarded sphere of personal autonomy. ${ }^{9}$ Thus, as this chapter demonstrates, a legal right to privacy presupposes an advanced legal protection of the individual and selfhood, suggesting that it could only develop when the premodern collective value systems and worldviews slowly started to disintegrate. ${ }^{10}$

In the eighteenth and nineteenth centuries, the legal concept of privacy started to encompass offences against a person's home, correspondence, dignity, family, or sexuality. New constitutions protected individuals against state interference with their homes and correspondence, permitting authorities or other individuals to enter or breach the hallowed sphere of privacy only under special circumstances and stringent conditions. The case law discussing e.g. the breaches of confidence, the publication of people's images, and unlawful entry into one's private quarters also helped protect what became known as the individual's rights to privacy or personality. From the mid-nineteenth century onwards, there has been an increase in the complaints of journalists invading private lives to publish scandalous stories. ${ }^{11}$ The modern press, mass media, and the Internet have further exacerbated privacy-related problems 'invading the sacred precincts of private and domestic life." ${ }^{12}$ Privacy has now become a human right protected by international treaties and conventions. In its Article 8, the European Convention on Human Rights from $195^{\circ}$ defines that:

8 E.g. Snyder T.J., "Developing Privacy Rights in Nineteenth-Century Germany: A Choice between Dignity and Liberty", American Journal of Legal History 58.2 (2018) 188-207, here esp. 192-207; [Anonymous] "The Right to Privacy in Nineteenth Century America", Harvard Law Review 94.8 (1981) 1892-1910. See also Ågren M., Domestic Secrets: Women \& Property in Sweden 1600-1857 (Chapel Hill, NC: 2009) 15-16.

9 Swanson J.A., The Public and the Private in Aristotle's Political Philosophy (Ithaca - London: 1992) 207 .

10 See also Meyer Spacks, Privacy 8: 'privacy marks a point of tension between individual and societal values'.

11 Snyder, "Developing Privacy" 193-204; [Anonymous], "The Right to Privacy"; Smith J.A., "Moral Guardians and the Origins of the Right to Privacy",Journalism and Communication Monographs 10.1 (2008) 63-110; Strömholm S., Right of Privacy and Rights of the Personality: A Comparative Survey (Stockholm: 1967) 25-31; Clapham, Human Rights 92; Warren S.D. Brandeis L.D., "The Right to Privacy", Harvard Law Review 4.5 (1890) 193-220.

12 E.g. Strömholm, Right of Privacy 16-18. Quotation from Warren - Brandeis, "The Right to Privacy" 195. 
1. Everyone has the right to respect for his private and family life, his home and his correspondence.

2. There shall be no interference by a public authority with the exercise of this right except such as is in accordance with the law and is necessary in a democratic society in the interests of national security, public safety or the economic well-being of the country, for the prevention of disorder or crime, for the protection of health or morals, or for the protection of the rights and freedoms of others.

But what do 'private life' and 'privacy' in the legal sense entail? The notion of 'privacy' is slippery to define, and today, it contains a cluster of aspects such as name and identity, physical, psychological, and moral integrity (including sexuality), honour, reputation, and private communication. In addition, even if freedom of conscience, thought, and religious matters are separately protected (Art. 9), these are closely related to private life and privacy. ${ }^{13}$

This chapter departs from the present-day legal understanding of privacy as discussed above, and it somewhat ahistorically projects some of the threads of the current legal perceptions of privacy back in time into medieval and early modern Sweden. As privacy as a legal and enforceable right is a modern legal concept, we can only use its present-day definition very cautiously when investigating past aspects of privacy and law. While medieval and early modern law in both Sweden and elsewhere distinguished between public and private law, the legal concept of privacy did not exist in the period, as this chapter demonstrates. Although certain legal concepts that are used primarily for the protection of privacy today, such as the peace of the home (Sw. hemfrid), have medieval origins, their contents have evolved, as will be analysed below. What today is primarily used for the protection of private life was for centuries limited to cases of forced entry and violent attack by one or several assailants. Consequently, a historical investigation of early modern privacy norms must, in the words of Peter von Moos, necessarily be a 'controlled anachronism' (ein kontrollierter Anachronismus). ${ }^{14}$

I will start this chapter with a few words about how public and private law were defined in early modern Swedish jurisprudence. I will focus especially on the concept of public crime and investigate some instances in which

13 Articles 8-9, The European Convention on Human Rights (1950), accessed online at https:// www.echr.coe.int/Documents/Convention_ENG.pdf, last accessed on 13 September 2021.

14 Von Moos P., "Das Öffentliche und Private im Mittelalter: Für einen kontrollierten Anachronismus", in Melville G. - von Moos P. (eds.), Das Öffentliche und Private in der Vormoderne (Cologne - Weimar - Vienna: 1998) 3-83, here 9-10. 
publicity or clandestinity had relevance in law. Then, drawing from the abovementioned cluster of present-day legal aspects of the right to privacy, I will discuss some examples of confidentiality, breaches of the peace of the home, and family life in the context of early modern Swedish law and privacy. As I will demonstrate, the early modern Swedish legal system did not recognise a right to privacy. Granted, certain crimes such as defamation awarded protection to a person's honour and there were, for example, some embryonic notions of secrecy. Nevertheless, as long as the collective mentality and criminal legal doctrine required that all crimes be punishable for the well-being of the society, there was little space for what later became a right to privacy in modernity.

\section{2 \\ The Publicity of Law and Space in the Early Modern Swedish Legal System}

In early modern Sweden, 'private' was defined through its opposite, 'public', and vice versa. In mid-sixteenth century examples from the Swedish language, a 'private person' (en privat person) in the sense of an ordinary citizen was opposed to a ruler (regerande). Thus, a private person was seen in contrast to the crown, the state, the general, or the public. In an early seventeenth-century example, 'public service' was juxtaposed with 'a peaceful private life.' ${ }^{15}$

But what, then, was 'private law'? The present-day distinction between private and public law is not identical with that in medieval or early modern law, which had its origins in antiquity, in Greek philosophy and Roman law. The Aristotelian public/private divide differentiated between the more private sphere of the household (oikos) and public political life (polis). ${ }^{16}$ In antiquity, Roman jurists drew the line between public and private law. Public law related to governance, administration and magistrates, as well as to religion and clergy, while everything else belonged to the sphere of private law. Interest formed another criterion: public law regulated the commonwealth and contributed to the public good (publice utilia, publica utilitas), while private law regulated and

\footnotetext{
15 Svenska Akademiens ordbok, entries: "offentlig", https://www.saob.se/artikel/?unik=0 _ooo1-0332.3RZo and "privat", https://www.saob.se/artikel/?seek=privat\&pz=1, last accessed on 13 September 2021; Laitinen R., Order, Materiality, and Urban Space in the Early Modern Kingdom of Sweden (Amsterdam: 2017) 216. For a more thorough discussion of the vocabulary of 'private' and 'public', see Savolainen P., Teksteistä rakennettu kaupunki: Julkinen ja yksityinen tila turkulaisessa kielenkäytössä ja arkielämässä (Turku: 2017) 52-59.

16 Swanson, The Public and the Private; von Moos, "Das Öffentliche und Private" 4-9.
} 
served private interests (privatim, privata utilitas). ${ }^{17}$ Medieval and early modern learned jurists developed these distinctions between private and public law, which were then adopted into Swedish law. ${ }^{18}$

David Nehrman (ennobled Ehrenstråhle, ${ }^{1695^{-1769}}$ ), the towering legal scholar of early modern Sweden, distinguished between public and private law largely following the classical Roman legal definition. Public law regulated the mutual relationship of the authorities and the subjects according to the 'fundamental laws of the Realm', while private law 'determined what was just and fair between the subjects in their private affairs, rights and property' ('Privata, som wisar hwad rätt och skiähl är emillan undersåtare uthi theras enskylte wärf, ährender, rättigheter och ägendom') ${ }^{19}$ Following the customary European definitions, Nehrman went on to describe that private law constituted 'Jurisprudentia Civilis', regulating ownership and contracts, and 'Jurisprudentia Criminalis', regulating wrongdoings. 'Jurisprudentia Oeconomica' was divided into various subfields regulating, e.g. the Church, military, agriculture, mining, and commerce. ${ }^{20}$ Police ordinances aimed at serving the common good, the governing and ordering of the state, which is why they largely regulated economic activities. ${ }^{21}$ Early modern Swedish criminal jurisprudence, exemplified by Nehrman, categorised crimes using several classifications: there were offences against God, the king, and the Swedish realm; against oneself or dead persons; against the life, health, or body of other

17 Digesta, 1.1.1.2., ed. T. Mommsen - P. Krüger, in Corpus iuris civilis 1 (Berlin: 1965) 29: 'Huius studii duae sunt positiones, publicum et privatum. Publicum ius est quod ad statum rei Romanae spectat, privatum quod ad singulorum utilitatem: sunt enim quaedam publice utilia, quaedam privatim. Publicum ius in sacris, in sacerdotibus, in magistratibus constitit. Privatum ius tripertitum est: collectum etenim est ex naturalibus praeceptis aut gentium aut civilibus'; Landau P., "Die Anfänge der Unterscheidung von ius publicum und ius privatum in der Geschichte des kanonischen Rechts", in Melville G. - von Moos P. (eds.), Das Öffentliche und Private in der Vormoderne (Cologne - Weimar - Vienna: 1998) 629-638.

18 Björne L., Patrioter och institutionalister: Den nordiska rättsvetenskapens historia 1 (Lund: 1995) esp. 27-39.

19 Nehrman David, Inledning til Then Swenska Iurisprudentiam civilem, af Naturens Lagh Och Sweriges Rikes äldre och nyare Stadgar uthdragen och vpsatt (Lund, Ludwig Decreaux: 1729) 23 .

$20 \quad$ Idem, Inledning til Then Swenska Iurisprudentiam civilem 24.

21 See Kotkas T., Royal Police Ordinances in Early Modern Sweden: The Emergence of Voluntaristic Understanding of Law (Leiden: 2014); Pihlajamäki H., "Executor divinarum et suarum legum: Criminal Law and the Lutheran Reformation", in Mäkinen V. (ed.), Lutheran Reformation and the Law (Leiden: 2006) 171-204, here 192-202. See also Laitinen R. - Lindström D., "Urban Order and Street Regulation in Seventeenth-Century Sweden”, Journal of Early Modern History 12 (2008) 257-287, here 261-271. 
persons; against the honour, reputation, and good name of others; against the property of others; and, finally, sexual crimes. ${ }^{22}$

Some crimes were considered public and others private. This distinction was largely determined by whether the crime injured the res publica, public interests, or individuals and their interests. In early modern Europe, public interest was construed very broadly as the guiding principle of criminal law: it was in the interest of the public good that no crimes remained unpunished (publicae utilitatis intersit, ne crimina remaneant impunita).${ }^{23}$ It was in everyone's best interests to guarantee the apprehension and punishment of criminals. Indeed, this principle formed a direct active duty for the crown and its representatives as the guardians of the commonwealth. From the High Middle Ages onwards, this principle of punishment of all criminals, based on Roman and medieval canon law and developed by medieval jurists, served as a catchphrase for all legal reforms that aimed at more effective control of misdeeds and punishment of all crimes and scandalous activities. After the inquisitorial procedure started to spread, certain infractions that had previously been considered 'private', only to be accused by the injured party, became considered public crimes. As such, they were prosecuted ex officio, regardless of whether or not the act had actually been mentioned or sanctioned in any criminal norm. ${ }^{24}$ Should the authorities fail to punish criminals who would then escape with impunity, these would become emboldened. Especially after the Reformation, there was emphasis on the argument of the necessity of punishing criminals to avert God's wrath and punishment of the whole community. ${ }^{25}$

The dividing line between public and private space in medieval and early modern Europe has generally been described as porous and situational. ${ }^{26}$

22 Nehrman, D., Inledning til Then Swenska Jurisprudentiam criminalem efter Sweriges Rikes Lag och Stadgar (Stockholm - Upsala, Gottfried Kiesewetter: 1756), unpaginated table of contents.

23 Quotation from Pope Innocent III's decretal Ut famae from 1203, x [Liber extra] 5.39.35, Corpus iuris canonici 2, ed. E. Friedberg (Leipzig: 1881) col. 904.

24 E.g. Fraher R.M., "Criminal Law of the High Middle Ages: 'Rei publicae interest, ne crimina remaneant impunita”, University of Illinois Law Review 3 (1984) 577-596, esp. 580-581; Jerouschek G. "Ne crimina remaneant impunita': Auf daß Verbrechen nicht ungestraft bleiben: Überlegungen zur Begründung öffentlicher Strafverfolgung im Mittelalter", Zeitschrift der Savigny-Stiftung für Rechtsgeschichte, Kanonistische Abteilung 97 (2003) 323-337; Landau P., “Ne crimina maneant impunita': Zur Entstehung des Öffentlichen Strafanspruchs in der Rechtswissenschaft des 12. Jahrhunderts", in Schmoeckel M. Condorelli O. - Roumy F. (eds.), Der Influss der Kanonistik auf die europäische Rechtskultur, 3: Straf- und Strafprozessrecht (Cologne - Weimar - Vienna: 2012) 23-35.

25 E.g. Pihlajamäki, "Executor" 182-192.

26 See Mette Birkedal Bruun's contribution to this volume. See also Laitinen R., "Rajoja ja avoimuutta 16oo-luvun kodeissa", Historiallinen Aikakausikirja 112.1 (2014) 20-31, here 
However, some researchers have stressed the role of legal norms in defining these two. For example, the Swedish ordinance on drunkenness (1733) allowed licensed taverns to serve alcohol until nine o'clock in wintertime and ten in the summertime. After this hour, these spaces - often the less well-off taverner's main living rooms - resumed their character of closed private homes. ${ }^{27}$

The Swedish law code of 1734 repeatedly defines public/private places. To take a specific case, it refers to cursing publicly 'i samqvem, krog eller källare, eller offenteliga på almänna gator och platsar' ('during social gatherings, in alehouses and restaurants or publicly in public streets or places') ${ }^{28}$ Fines for defamatory acts or speech were doubled if the insulting had taken place 'i stort samqvem, eller å almän gato, ther mycker folk är' ('in a big gathering or on a public street with many people') ${ }^{29}$ The same applied to assault on public streets and highways, shouting or verbal assault on public streets, highways, or alleys, and damaging or destroying public bridges, milestones, or other things placed there for public utility or decoration. ${ }^{30}$ Another example of the legal regulation of publicity/clandestinity is the necessity of not keeping a pregnancy and birth private. Both hiding the pregnancy and secret accouchement were constituting elements of infanticide, a serious crime punishable by death. Thus, an unmarried pregnant woman who sought solitude when about to give birth in order to avoid being sentenced for sexual crime risked execution if the baby died..$^{31}$

Moreover, it was no private matter whom townspeople had living or staying in their homes: since the late Middle Ages, legal norms - i.e. town ordinances regulated such matters. ${ }^{32}$ As Riitta Laitinen has discussed in detail, the law

esp. 26-27; idem, Order, Materiality, and Urban Space in the Early Modern Kingdom of Sweden (Amsterdam: 2017) 17, 60, 191, 201, 204, and 217-221; Kaartinen M., "Public and Private: Challenges in the Study of Early Modern Women's Lives”, in Korhonen A. Tuohela K. (eds.), Time Frames: Negotiating Cultural History (Turku: 2002) 89-104, here 94-95; Ariès P., "Introduction", in Chartier R. (ed.), A History of Private Life III: Passions of the Renaissance, trans. A. Goldhammer (Cambridge, MA - London: 1989) 1-11.

27 Savolainen, Teksteistä 94.

28 E.g. 3:1, Chapter on Crime (Sw. Missgiernings Balk), Sveriges Rikes Lag, gillad och antagen på riksdagen år 1734: Till 250-årsdagen av lagens tillkomst efter den första $i$ antikva tryckta upplagen av år 1780, intr. S. Jägerskiöld (Lund: 1984 [1780]) 127. See also Savolainen, Teksteistä 168.

29 6o:6, Chapter on Crime, Sveriges Rikes Lag, 1734 173-174: '[... s] ker thet i stort samqvem, eller å almän gato, ther mycker folk är'; Savolainen, Teksteistä 121.

$30 \quad$ 21:7-9, Chapter on Crime, Sveriges Rikes Lag, 1734145.

31 E.g. 16:1-2, Chapter on Crime, Sveriges Rikes Lag, 1734 137-138: '[16:1 ...] thet ej uppenbarar förr födslen, söker enslighet vid sielfva födslen och therefter lägger fostret å lön'.

32 See, e.g. Stockholms stads tänkeböcker 1474-1483 samt burspråk, ed. E. Hildebrand (Stockholm: 1917). 
regulated the right of various groups - foreigners, vagrants, paupers, or people of ill repute - to sojourn in town as well as the right townspeople had to accommodate them. The town authorities could inspect houses in search of unregistered people, and householders who caught lodging vagrants had to evict their illicit lodgers. In addition, the householders were fined and threatened with expulsion themselves. ${ }^{33}$ Even here, the interests of the common good and maintaining order surpassed what we today would consider part of 'privacy' and individual autonomy.

Thus, early modern Swedish law distinguished between public and private law. The crown defended the public interests and guaranteed that all criminals be punished suitably. This was an overriding concern. The dividing line between private and public space was porous, even if the law expressly identified certain places and occasions as public and gave them special meaning.

\section{3}

\section{Protection of Confidentiality and Secrecy?}

Citing Sasha Handley, who refers to sleep, early modern privacy experiences represent 'important pieces of a more complex jigsaw [...] which varied according to wealth, status, gender, location, occupation, age and household circumstance. ${ }^{34}$ Privacy was not equally available to all. Even if privacy had its drawbacks, researchers have argued that because both secular and ecclesiastical authorities monitored and controlled people in the early modern period, it was a rare and precious commodity. ${ }^{35}$ Generally, privacy was achieved only for short periods as 'breathing spaces' and breaks 'from social pressure. ${ }^{36}$ How, then, did the legal system perceive and protect privacy?

As mentioned above, secrecy and breaches of confidence have been seen as belonging to the sphere of privacy. ${ }^{37}$ Similarly, in their well-known 1890 article, Samuel D. Warren and Louis D. Brandeis discussed privacy rights through constructions related to breaches of confidence and/or contract, defamation, and intellectual property law. ${ }^{38}$ Although a 'right to privacy' did not exist at the time, medieval and early modern public office-holding could require oaths confirming secrecy (iuramentum taciturnitatis), thus linking together trust,

\footnotetext{
33 Laitinen, Order 8o-106.

34 Handley S., Sleep in Early Modern England (New Haven - London: 2016) 116.

35 Huebert, Privacy $7-8$.

36 Meyer Spacks, Privacy 8; Ariès P., "Introduction" 1, 5 .

37 See also Lochrie K., Covert Operations: The Medieval Uses of Secrecy (Philadelphia, PA: 1999).

38 Warren - Brandeis, "The Right to Privacy".
} 
power, and information. State secrets, deliberations behind closed doors had to remain private. Public officials, judges, and town councillors took special oaths to safeguard this. Priests were required to keep the seal of the confessional and not divulge intimate confessions, while the Hippocratic oath imposed strict secrecy and confidentiality on doctors, who had been taking it ever since antiquity.

Swedish medieval law contained a section on the oath of the Councillors of the Realm, i.e. the secular and ecclesiastical magnates sitting in the Swedish royal council, including a passage about not disclosing anything the king wanted to be kept secret (Sw. lönlikit). The Code of 1734 contained a corresponding section. ${ }^{39}$ The judges and staff of the Swedish appeals courts, first established in 1614, also had to swear an oath of secrecy, not to divulge to the parties or others what went on behind the tribunal's closed doors. ${ }^{40}$ However, this requirement of secrecy only applied to special official oaths.

Generally, Swedish law did not consider breaches of the secrecy of letters between the original correspondents punishable even if the exchange was carried out in confidence, 'sub rosa' ${ }^{41}$ According to Nehrman, the exposed correspondent could only blame him/herself for trusting an unworthy person. ${ }^{42}$ Nevertheless, the Swedish Code of 1734 that came into force in 1736 , came to award a person's private letters some protection: it became punishable to damage or shame a person by opening his or her letters, reading them oneself, or permitting someone else to read them. Divulging or spreading their contents also constituted a crime. The punishment was an amercement of twenty dalers or more. In addition, the culprit would be punished by infamy and loss of honour if the judge thought the crime merited this. Thus, the penalty was discretionary and depended on the damage done to the victim. ${ }^{43}$ This applied to situations in which the offender was neither the sender nor the recipient of the letter.

39 8:1, Chapter on the King (Sw. "Konungx Balken"), Corpus iuris Sueo-Gotorum antiqui = Samling af Sweriges gamla lagar [hereafter CISGA] 12: Konung Christoffers landslag, ed. C.J. Schlyter (Lund: 1869) 26; 4:5, "Missgiernings Balk", Sveriges Rikes Lag, 1734 129. See also Webb, Privacy and Solitude 210.

40 Riksarkivet [Stockholm, Sweden], Svea Hovrätt, Huvudarkivet, A I a 1:1, no page.

41 'Sub rosa', meaning literally 'under the rose', also means 'in secrecy' or 'confidentially'. The rose has denoted silence, secrecy, and confidentiality ever since antiquity.

42 Nehrman, Inledning til Then Swenska Jurisprudentiam criminalem 315-316.

43 8:4, Chapter on Crime, Sveriges Rikes Lag, 1734 133: '4. §. Bryter någor up annars mans bref, läser, eller gifver annan at läsa, uppenbarar och utsprider thet, som skrifvit är, och söker ther med hans skada och nesa, som thet rörer; böte tiugu daler, eller mera, och vare ther til ärelös, om brottet thet förtienar'. 
By and large, offences against privacy or private life may perhaps correspond best to offences against the honour, reputation, and good name of others in early modern Sweden. This included various forms of slander and libel, accusing someone of a crime or insulting another. If the offending claim or words were true, the act was not punishable. However, if the insult did not involve claims of a committed crime but only intended to offend, dishonour, and slander, whether in words, writings, or drawings, the perpetrator could still be punished. ${ }^{44}$ In addition to verbal insults, prints and broadsides were also prosecuted as slanderous in early modern Sweden.

In early modern Swedish legal practice, norms against slander and injuring another person's reputation and honour were much used. While it was criminal to open someone else's letter and publicise its contents, divulging secrets was not normally punishable. Certain offices and professions required confidentiality and secrecy, and sometimes were accompanied by oaths. Nevertheless, privacy issues only became increasingly important when the modern press developed as a mass medium in the latter half of the nineteenth century.

The privacy of the home, which in the nineteenth century became increasingly fundamental, was very different in medieval and early modern law. At least since the mid-thirteenth century, the peace of the home and house (hus- och hemfrid) was especially protected in Swedish law, as an important component of a cluster of peace legislation. But how did Swedish law define breaking the peace of the home, and did it actually include the legal protection of presentday perceptions of privacy?

According to medieval Swedish law, the scope of the peace of the home was customarily a space within an enclosure of fences and buildings. This sphere of protection extended even to buildings standing apart, such as saunas and privies. Both in medieval and early modern law, the breach of this peace had to involve violent entry into another person's home or house, ship, or farm against the proprietor's or lawful possessor's will, with evil intentions and a purpose to inflict injury or damage. The breach of this peace was called 'hemgång' ('homegoing') ${ }^{45}$ However, if the violent entry was not revenge but took place in the

44 E.g. 6o:4-6, ibidem 173-174; Nehrman, Inledning til Then Swenska Jurisprudentiam criminalem 300-319. Also Laitinen, Order 138.

45 E.g. 1 and 4, Chapter on Peace Legislation (Sw. "Edzöris Balken"), CISGA 11: Konung Magnus Erikssons stadslag, ed. C.J. Schlyter (Lund: 1865), 292-295; 1, 5, Chapter on Peace 
heat of the moment, the peace of the home was not breached. Also, there had to be a physical assault upon a person as mere threats did not constitute the crime of breaching the peace of the home. ${ }^{46}$ Some earlier provincial laws had also awarded a sleeping person and a person in a privy (hemlighusfrid; lit. 'secret house peace') special protection, but this was because of the helplessness involved, not privacy. ${ }^{47}$

The legal definition of violating the peace of the home stressed breaking and entering into this protected sphere with vengeful intention and assaulting one or several persons inside. Coming to the gate and hitting it has been identified as the first and the most important individual act. However, whether the attacker(s) carried weapons and wielded these already on entry was also legally relevant. ${ }^{48}$ As Laitinen's analysis of 21 'peace of the home' cases from Turku in 1640-166o indicates, violence or the threat of violence, suggesting evil intent, was an essential condition of the crime. Another was breaching the boundaries of the protected sphere of the home, usually through a gate or door. ${ }^{49}$ In the later eighteenth century, nocturnal and illicit entry and a suspicion of wrongdoing may in practice have been considered sufficient. ${ }^{50}$ However, it would require more thorough research of primary sources to specify more exactly when the punishments for breaching the peace of the home actually started to emphasise elements of privacy instead of forcible entry and violence.

As Nehrman observed in the eighteenth century, many acts of violence were not considered violations of the peace of the home because of the stringent definition of the law. However, other acts of violence in homes and houses were punishable as violent crimes and by virtue of the special criminalisation of the peace of the Sabbath, which was also used when punishing minor disturbances. ${ }^{51}$ In all medieval and early modern Western societies, including Sweden, the officials were authorised to enter houses and homes in pursuit

Legislation, CISGA 12: Konung Christoffers landslag, ed. C.J. Schlyter 269-272; Laitinen, "Rajoja", esp. 21-23; Laitinen, Order 194-195, 204-214.

46 Nehrman, Inledning [...] Jurisprudentiam criminalem 209: ‘Genom hemgång brytes husoch hemfrid, tå någon går, med argt upsåt, och berådde mode, at skada giöra, hem til annan, i thess gård eller hus, farkost eller skiep, egit eller thet man af ägaren hafwer tilstånd, at bebo och nyttia'.

47 Korpiola M., “'The People of Sweden Shall Have Peace': Peace Legislation and Royal Power in Later Medieval Sweden", in Musson A. (ed.), Expectations of the Law in the Middle Ages (Bury St Edmunds: 2001) 35-51.

48 Hassan Jansson K., "Våld som aggression eller kommunikation? Hemfridsbrott 15501650", Historisk Tidskrift 126.3 (2006) 429-452, here 434-436, 440, and 443.

49 Laitinen, "Rajoja" 20-31; Laitinen, Order 194-195.

$50 \quad$ Savolainen, Teksteistä 225 .

$5^{1} \quad$ Nehrman, Inledning [...] Jurisprudentiam criminalem 219. 
of criminals, vagrants, stolen goods, and contraband. By the eighteenth century, Anglo-American law awarded remedies for unauthorised or excessive breaches of the tranquillity, sacredness, and inviolability of the home, in accordance with the maxim that 'a man's house is his castle', against authorities, landlords, and third parties. In the course of the nineteenth century, the development was furthered to the point that 'the law had erected high walls around the family home by extending criminal penalties for and civil remedies against intrusion by strangers'. Criminal law also protected the home against violations such as peeping and eavesdropping. ${ }^{52}$ Similarly, nineteenth-century continental constitutions protected people's dwellings against state violations, e.g. in the form of unauthorised house searches. ${ }^{53}$

Such perceptions of privacy were not included in the protection of the peace of the home in the Swedish law of 1734, which had a very narrow and different view of the breach of the peace. For example, eavesdropping and secret peeping into homes were not specifically mentioned in Swedish early modern law. Rather, in Sweden as elsewhere, people peering through holes and chinks or listening at doors and windows helped to discover many (sexual) offenders. ${ }^{54}$ This was in accordance with the leading criminal law principle requiring the punishment of all malefactors. In a society in which every criminal was to be chastised in order to protect the community, such neighbourly vigilance in the form of eavesdropping and peeping that resulted in the unearthing of wrongdoings could be considered virtuous and commendable rather than offensive.

However, the neighbourhood law in the Chapter of Buildings and municipal police ordinances regulated damages to walls and windows, which could have important privacy implications. Eavesdropping or peeping could be punishable if it included damaging a building owned by another person, e.g. making holes or enlarging chinks. In England, the neighbourhood legislation guaranteed some light as well as privacy in towns like London. ${ }^{55}$ In Sweden, creating window openings into other people's yards was apparently relatively rare and may have required the consent of the yard owner. ${ }^{56}$ As windows could also

$5^{2}$ [Anonymous], "The Right to Privacy" 1894-1898 (quotation 1896); Cuddihy W. Hardy B.C., "A Man's House Was Not His Castle: Origins of the Fourth Amendment to the United States Constitution", The William and Mary Quarterly 37.3 (1980) 371-400. I owe this reference to Mette Birkedal Bruun, which I acknowledge with thanks.

53 Snyder, "Developing Privacy Rights" 196-200.

54 Orlin L.C., Locating Privacy in Tudor London (Oxford: 2007) 152, 154, and 177-192.

55 Loengard J.S., "Common Law and Custom: Windows, Light, and Privacy in Late Medieval England", in Jenks S. - Rose J. - Whittick C. (eds.), Law, Lawyers and Texts: Studies in Medieval Legal History in Honour of Paul Brand (Leiden: 2012) esp. 286-298.

Laitinen, Order 202-203. 
be used for entry and exit, these norms may have aimed both at preventing trespassing as well as granting some privacy. The Swedish Code of 1734 criminalised malicious damage done to another person's building or planking with a twenty-daler amercement, and damaging fences or gates was also finable. In addition to the 1734 Code or statutes, nineteenth-century local Finnish police ordinances considered damaging and vandalising other people's houses or fences punishable with fines and damages. ${ }^{57}$ Whether such norms were actually used for the protection of the privacy of the inhabitants or only for protecting private property from damage as was tradition, would again require delving deep into court records.

Laitinen's analysis of mid-seventeenth-century Turku suggests that homes did not award much privacy, always being 'spaces of communal encounter'. Consequently, people could not expect complete seclusion. " $[\mathrm{A}] \mathrm{s}$ the homes were open spaces, "open houses", there was no privacy, but also vice versa: since there was no privacy, homes were open spaces'. ${ }^{58}$ Some households were less open, awarding more privacy than others, as Panu Savolainen's research on later eighteenth-century Turku suggests. However, the legal protection granted to privacy had not changed much in a century. Even if the peace of the home today includes protection from eavesdropping and peeping in addition to all sorts of unlawful entry, the early modern definition required violence and malicious intent. It is yet to be investigated when exactly the medieval interpretation changed in law and practice to the protection of privacy in Sweden and Finland during the process of modernisation.

\section{Privacy of Family Life: Conflicting Trends}

Traditionally, households and families have belonged to the core of private life and privacy, and the propagation of the family was fundamental for the purposes of property transfer. In medieval Europe, the sexual union of the married couple was no private affair as the Catholic Church regulated and defined the borders of sexuality. ${ }^{59}$ Due to ecclesiastical influence, a clear-cut distinction between matrimony and other, illicit, unions was drawn in later-medieval Scandinavia. Children born in what the Church perceived to be unlawful

57 20:12, Chapter on Crime, Sveriges Rikes Lag, 1734 143; 5:8, Chapter on Buildings, ibidem 67; §19, Polis-ordning för Fredrikhamns stad: Gillad och fast ställd den 6 Augusti 1850 (Hamina: 1850) no page; §22, Polisordning för Helsingfors stad [1864] (Helsinki: 1864).

58 Laitinen, Order 262.

59 E.g. Brundage J.A., Law, Sex and Christian Society in Medieval Europe (Chicago - London: 1987) passim; Lochrie, Covert Operations 24-55. 
unions came to lose their inheritance rights. Consequently, claims of illegitimacy could be and were occasionally raised in inheritance disputes. Paternity was not a private affair.

Even if legitimate birth could be - and occasionally was - challenged, families were granted some protection against malicious or frivolous accusations through particular legal presumptions. Certain Swedish medieval laws presumed the normal term of pregnancy to be nine months, the 'lawful months'. Yet, children were accepted as their fathers' legitimate issues if born within ten months, after the so-called 'delay month', of their father's death, disappearance, or departure. In later medieval laws, in force until 1736, paternity was ascribed to the husband during forty weeks. ${ }^{60}$ Moreover, Swedish law adopted the Roman presumption of paternity (pater est quem nuptiae demonstrant) that is still upheld in many European legal systems: no contrary evidence existing, a married woman's husband was and is presumed to have fathered any child she gives birth to. ${ }^{61}$ The principle provided family life some protection from covetous relatives.

Swedish medieval law also granted couples some privacy in adultery cases. While learned jurisprudence had considered adultery a public crime of which anyone could accuse another, Swedish law contained the rule that only spouses could normally accuse each other of adultery. Others, such as ecclesiastical or secular officials, could only initiate criminal proceedings if the injured party had first publicly accused his or her spouse without later withdrawing the charge. The actions of the adulterous couple could also publicise the liaison: starting to cohabit, eloping together or the adulteress's pregnancy. ${ }^{62}$

Yet, when extramarital intercourse was suspected, members of the community were authorised to intrude upon the privacy of the household and the especially hallowed space of the home. If there were two witnesses to the crime and the movements of the parties, or if the couple was caught in the act, both the threshold of accusation and proof were simultaneously taken care

6o E.g. 10:16, Chapter on Inheritance (Sw. “Ærfpæ Balken”), CISGA 3: Uplandslagen, ed. C.J. Schlyter (Stockholm: 1834) 114-115; 5, Chapter on Inheritance, CISGA 11: Konung Magnus Erikssons stadslag, ed. C.J. Schlyter 81; 6, Chapter on Inheritance, CISGA 12: Konung Christoffers landslag, ed. C.J. Schlyter 82.

61 E.g. Treggiari S., Roman Marriage: Iusti Coniuges from the Time of Cicero to the Time of Ulpian (Oxford: 1991) 307; 7:2, Chapter on Inheritance, CISGA 5: Westmannalagen, ed. C.J. Schlyter (Lund: 1841) 124 .

62 See, e.g. 6, Chapter on Inheritance, CISGA 3: Uplandslagen, ed. C.J. Schlyter 108; Korpiola M., "'Only the Husband Can Accuse the Wife of Adultery and She Him:' Prosecuting and Proving Adultery in Medieval Sweden", Zeitschrift der Savigny-Stiftung für Rechtsgeschichte, Kanonistische Abteilung 100 (2014) 223-261 and the sources cited there. See also von Moos, "Das öffentliche und das Private" 31-32. 
of. Apparently, Swedish medieval law assumed that the act would occur in a bed indoors. ${ }^{63}$ Both medieval and early modern Swedish court records describe scenes in which the witnesses burst in and surprised the adulterous couple partially undressed or even in the bed together. As suspected criminals, they were entitled to even less privacy than ordinary people. ${ }^{64}$ Moreover, seventeenth-century practice indicates that, despite the law, adultery - like other crimes - became increasingly prosecuted on the basis of rumours and suspicion due to the more effective and well-coordinated local secular and ecclesiastical control systems. ${ }^{65}$

Yet, matrimonial property arrangements seem to have been increasingly defined as 'domestic secrets' by late seventeenth-century lawyers. Both parties brought property to the union, and this property was regulated differently, depending on which party it belonged to and whether it was inherited or acquired, land or moveable property. For outsiders such as creditors the matrimonial estate was opaque. They could not know what property actually belonged to the husband and what to the separate uxorial assets as there were no efficient and obligatory means of publicly registering ownership. Transparency-increasing legal institutions such as estate inventories and public registration were only slowly emerging in the seventeenth and eighteenth centuries. Paradoxically, the situation led to both an increase and a decrease in privacy. ${ }^{66}$ Some lawyers criticised the criminalisation of family theft (bodrägt), i.e. spouses or children embezzling family property, preferring to leave such matters to private life. However, the crime of family theft was included in the 1734 Code, but it became a so-called complainant offence that only the injured parties could prosecute. ${ }^{67}$

Within families and households, bodily integrity was very different in early modern Sweden from today. Writing in the eighteenth century, Nehrman defined the distinction between criminal violence and licit violence. Punishable violence was any violent act against the will of a person that the perpetrator forced the victim to tolerate and suffer upon their body or property. Moreover, the perpetrator was not entitled to commit the deed nor was the victim obliged to suffer it. ${ }^{68}$ This may sound relatively modern as far as,

63 E.g. 15:3, Chapter on the Church (Sw. "Kirkiu Balken"), CISGA 3: Uplandslagen, ed. C.J. Schlyter 62-63.

64 See examples in Korpiola, "'Only the Husband".

65 E.g. Aalto S., Kirkko ja kruunu siveellisyyden vartijoina: Seksuaalirikos, esivalta ja yhteisö Porvoon kihlakunnassa 1621-1700 (Helsinki: 1996).

66 Ågren, Domestic Secrets 13-17, 90-97. Cf. Lochrie, Covert Operations 148-149.

67 Ågren, Domestic Secrets 86-87.

68 Nehrman, Inledning til Then Swenska Jurisprudentiam criminalem 205. 
for example, bodily integrity is concerned. Nevertheless, considering the right of officials to administer bodily violence upon criminals and the hierarchical authority of social superiors to correct and chastise wives, children, servants, students, employees, and so on, in practice, bodily integrity and privacy were quite limited. ${ }^{69}$ In early modern Sweden, as elsewhere, the private realm of the household was the microcosm of the political body. If a man failed to control and master his own household and its members, it was a discredit to him and his authority even in the public sphere. ${ }^{70}$ Yet, after 1734 , legislators apparently tended to consider that domestic interspousal violence belonged to the private sphere instead of being publicly prosecuted. ${ }^{71}$

To sum up, in the early modern world, family life belonged to private law and the most private sphere. Here we can find some embryonic protection of the family from malicious lawsuits (e.g. presumption of paternity). However, sexual life was not private when it was criminal as all non-marital sex unfailingly was, and all sexual offenders were to be discovered and punished according to early modern criminal law ideology. Societal hierarchies permitted moderate licit violence as chastisement within the household even after corporal penalties had been removed from the law. The European trends of idealising domesticity spread to the North, especially during the nineteenth century. The family, more intimate and affectionate than before, increasingly separated itself spatially from their servants and exhibited heightened concerns for privacy even from the domestic help. ${ }^{72}$ Sentimental and individualistic perceptions of the family started to replace older notions of the house(hold) and the patriarchal order, and both masters and servants came to turn their backs on each other. Even the word 'family' became predominantly used for the unit of parents and children rather than a kin-group or household. Bourgeois family life became a refuge from the public sphere. ${ }^{73}$ The new modern legal perceptions of privacy and its protection emerged from this development.

69 E.g. 30 and 36:1-2, Chapter on Crime, Sveriges Rikes Lag, 1734 152-153, 156.

$70 \quad$ E.g. Orlin L.C., Private Matters and Public Culture in Post-Reformation England (Ithaca London: 1994) 18, 71-73, 85-86, 134-136.

71 Ågren, Domestic Secrets 86-87; 36:1 and 51, Chapter on Crime, Sveriges Rikes Lag, 1734 $156,166$.

72 E.g. Maza S., Servants and Masters in Eighteenth-Century France: The Uses of Loyalty (Princeton, NJ: 1983) esp. 253-266, 326-327.

73 Häggman K., Perheen vuosisata: Perheen ihanne ja sivistyneistön elämäntapa 180o-luvun Suomessa (Helsinki: 1994) 40-58, 134-136, 176-179; Ariès, "Introduction" 7-8. 
As Lena Cowen Orlin observes, early modern privacy was, for several reasons, a scarce commodity. The 'built environment' left little room for privacy as even private homes were multipurposed centres of consumption and production. Sharing space commonly resulted in a high 'social density', and people were encouraged to monitor each other. ${ }^{74}$ Consequently, privacy has been identified as having been 'an emerging expectancy' in the early modern period. ${ }^{75}$

While the possibility to enjoy privacy appears as slowly starting to emerge in early modern society, the legal protection it was awarded during the period can be called embryonic at best. Privacy as a right or a special interest protected by law as today did not exist at this time. Despite this assertion, I have approached the topic using present-day legal definitions of the privacy cluster as the starting point of my controlled anachronistic exercise. Consequently, I have investigated the main strands of the legal protection of 'privacy' in early modern Swedish law: confidentiality and secrecy, protection against slander and libel, peace of the home against violent intruders, and a certain protection of family secrets against outsiders.

One of the main factors contributing to the lack of such protection was that the legal system was based on another, more communal and religious value system insisting on punishing all crimes. This superior concern overrode any nascent notions of privacy. Thus, for example eavesdropping and peeping were virtues, not vices, if they resulted in bringing criminals to justice.

Kai Häggman has observed that "the "nuclearisation" of the family in the nineteenth and early twentieth centuries was about the efforts of adult persons such as servants, lodgers, or employees to free themselves from the custody and control of their masters, landlords/ladies, and employers that reached very personal levelss. ${ }^{76}$ The discovery of privacy in new ways was part of this process. The development of nineteenth-century European police states threatened the confidentiality of correspondence or the peace of the home. The modernising newspaper industry posed other potential threats to an individual's private sphere. All gave impetus to the developing perceptions of privacy as a special interest and its more effective legal protection. Consequently, a legally protected and enforceable right to privacy became redefined and started its legal ascendancy into modern law, but that is outside the scope of this article.

74 Orlin, Locating Privacy 226. See also Collomp A., "Families: Habitations and Cohabitations", in Chartier R. (ed.), A History of Private Life, vol. 3, 493-529, esp. 501-509, 513.

75 Huebert, Privacy 295.

76 Häggman, Perheen vuosisata 179. 


\section{Bibliography}

\section{Manuscripts}

Riksarkivet [Stockholm, Sweden], Svea Hovrätt, Huvudarkivet, A I a 1:1.

\section{Printed Books}

Aalto S., Kirkko ja kruunu siveellisyyden vartijoina: Seksuaalirikos, esivalta ja yhteisö Porvoon kihlakunnassa 1621-1700 (Helsinki: 1996).

Ågren M., Domestic Secrets: Women \& Property in Sweden 1600-1857 (Chapel Hill, NC: 2009).

[Anonymous] "The Right to Privacy in Nineteenth Century America", Harvard Law Review 94.8 (1981) 1892-1910.

Ariès P., "Introduction", in Chartier R. (ed.), A History of Private Life III: Passions of the Renaissance, trans. A. Goldhammer (Cambridge, MA - London: 1989) 1-11.

Björne L., Patrioter och institutionalister: Den nordiska rättsvetenskapens historia 1 (Lund: 1995).

Brundage J.A., Law, Sex, and Christian Society in Medieval Europe (Chicago - London: 1987).

Corpus iuris Sueo-Gotorum antiqui = Samling af Sweriges gamla lagar 3: Uplandslagen, ed. C.J. Schlyter (Stockholm: 1834).

Corpus iuris Sueo-Gotorum antiqui = Samling af Sweriges gamla lagar 5: Westmannalagen, ed. C.J. Schlyter (Lund: 1841).

Corpus iuris Sueo-Gotorum antiqui = Samling af Sweriges gamla lagar 11: Konung Magnus Erikssons stadslag, ed. C.J. Schlyter (Lund: 1865).

Corpus iuris Sueo-Gotorum antiqui = Samling af Sweriges gamla lagar 12: Konung Christoffers landslag, ed. C.J. Schlyter (Lund: 1869).

Clapham A., Human Rights: A Very Short Introduction (Oxford: 2007).

Collomp A., "Families: Habitations and Cohabitations", in Chartier R. (ed.), A History of Private Life III: Passions of the Renaissance, trans. A. Goldhammer (Cambridge, MA - London: 1989) 493-529.

Cuddihy W. - Hardy B.C., "A Man's House Was Not His Castle: Origins of the Fourth Amendment to the United States Constitution", The William and Mary Quarterly $37 \cdot 3$ (1980) 371-40o.

Digesta, 1.1.1.2., eds. T. Mommsen - P. Krüger, in Corpus iuris civilis, vol. 1 (Berlin: 1965).

Fraher R.M., "Criminal Law of the High Middle Ages: 'Rei publicae interest, ne crimina remaneant impunita”, University of Illinois Law Review 3 (1984) 577-596.

Häggman K., Perheen vuosisata:Perheen ihanne ja sivistyneistön elämäntapa 180o-luvun Suomessa (Helsinki: 1994).

Handley S., Sleep in Early Modern England (New Haven - London: 2016). 
Hassan Jansson K., "Våld som aggression eller kommunikation? Hemfridsbrott 15501650", Historisk Tidskrift 126.3 (2006) 429-452.

Huebert R., Privacy in the Age of Shakespeare (Toronto - Buffalo - London: 2016).

Jerousche G., "Ne crimina remaneant impunita': Auf dass Verbrechen nicht ungestraft bleiben: Überlegungen zur Begründung öffentlicher Strafverfolgung im Mittelalter", Zeitschrift der Savigny-Stiftung für Rechtsgeschichte, Kanonistische Abteilung 97 (2003) 323-337.

Kaartinen M., "Public and Private: Challenges in the Study of Early Modern Women's Lives", in Korhonen A. - Tuohela K. (eds.), Time Frames: Negotiating Cultural History (Turku: 2002) 89-104.

Korpiola M., “The People of Sweden Shall Have Peace': Peace Legislation and Royal Power in Later Medieval Sweden", in Musson A. (ed.), Expectations of the Law in the Middle Ages (Bury St Edmunds: 2001) 35-51.

Korpiola M., "'Only the Husband Can Accuse the Wife of Adultery and She Him': Prosecuting and Proving Adultery in Medieval Sweden", Zeitschrift der SavignyStiftung für Rechtsgeschichte, Kanonistische Abteilung 100 (2014) 223-261.

Kotkas T., Royal Police Ordinances in Early Modern Sweden: The Emergence of Voluntaristic Understanding of Law (Leiden: 2014).

Laitinen R., "Rajoja ja avoimuutta 16oo-luvun kodeissa", Historiallinen Aikakausikirja $112.1(2014) 20-31$.

Laitinen R., Order, Materiality, and Urban Space in the Early Modern Kingdom of Sweden (Amsterdam: 2017).

Laitinen R. - Lindström D., "Urban Order and Street Regulation in Seventeenth-Century Sweden", Journal of Early Modern History 12 (2008) 257-287.

Landau P., "Die Anfänge der Unterscheidung von ius publicum und ius privatum in der Geschichte des kanonischen Rechts", in Melville G. - von Moos P. (eds.), Das Öffentliche und Private in der Vormoderne (Cologne - Weimar - Vienna: 1998) $629-638$.

Landau P., “Ne crimina maneant impunita': Zur Entstehung des Öffentlichen Strafanspruchs in der Rechtswissenschaft des 12. Jahrhunderts", in Schmoeckel M. Condorelli O. - Roumy F. (eds.), Der Influss der Kanonistik auf die europäische Rechtskultur, 3: Straf- und Strafprozessrecht (Cologne - Weimar - Vienna: 2012) 23-35.

Liber extra, in Corpus iuris canonici vol. 2, ed. E. Friedberg (Leipzig: 1881).

Lochrie K., Covert Operations: The Medieval Uses of Secrecy (Philadelphia, PA: 1999).

Loengard J.S., "Common Law and Custom: Windows, Light, and Privacy in Late Medieval England", in Jenks S. - Rose J. - Whittick C. (eds.), Law, Lawyers and Texts: Studies in Medieval Legal History in Honour of Paul Brand (Leiden: 2012) 279-298. 
Maza S., Servants and Masters in Eighteenth-Century France: The Uses of Loyalty (Princeton, NJ: 1983).

Meyer Spacks P., Privacy: Concealing the Eighteenth-Century Self (Chicago - London: 2003).

Nehrman David, Inledning til Then Swenska Iurisprudentiam civilem, af Naturens Lagh Och Sweriges Rikes äldre och nyare Stadgar uthdragen och vpsatt (Lund, Ludwig Decreaux: 1729).

Nehrman David, Inledning til Then Swenska Jurisprudentiam criminalem efter Sweriges Rikes Lag och Stadgar (Stockholm - Uppsala, Gottfried Kiesewetter: 1756).

Orlin L.C., Private Matters and Public Culture in Post-Reformation England (Ithaca London: 1994).

Orlin L.C., Locating Privacy in Tudor London (Oxford: 2007).

Pihlajamäki H., "Executor divinarum et suarum legum: Criminal Law and the Lutheran Reformation", in Mäkinen V. (ed.), Lutheran Reformation and the Law (Leiden: 2006) 171-204.

Polis-ordning för Fredrikhamns stad: Gillad och fast ställd den 6 Augusti 1850 (Hamina: 1850).

Polisordning för Helsingfors stad [1864] (Helsinki: 1864).

Reiman J.H., "Privacy, Intimacy, and Personhood", Philosophy \& Public Affairs 6.1 (1976) $26-44$.

Savolainen P., Teksteistä rakennettu kaupunki: Julkinen ja yksityinen tila turkulaisessa kielenkäytössä ja arkielämässä (Turku: 2017).

Smith J.A., "Moral Guardians and the Origins of the Right to Privacy", Journalism and Communication Monographs 10.1 (2008) 63-110.

Snyder T.J., "Developing Privacy Rights in Nineteenth-Century Germany: A Choice between Dignity and Liberty", American Journal of Legal History 58.2 (2018) 188-207.

Stockholms stads tänkeböcker 1474-1483 samt burspråk, ed. E. Hildebrand (Stockholm: 1917).

Strömholm S., Right of Privacy and Rights of the Personality: A Comparative Survey (Stockholm: 1967) 25-31.

Svenska Akademiens ordbok, available online at https://www.saob.se/, accessed on 13 September 2021.

Sveriges Rikes Lag, gillad och antagen på riksdagen år 1734: Till 250-årsdagen av lagens tillkomst efter den första i antikva tryckta upplagen av år 1780, intr. S. Jägerskiöld (Lund: 1984 [1780]).

Swanson J.A., The Public and the Private in Aristotle's Political Philosophy (Ithaca London: 1992).

The European Convention on Human Rights (1950), accessed online at https://www .echr.coe.int/Documents/Collection_Convention_1950_ENG.pdf, accessed on 13 September 2021. 
Treggiari S., Roman Marriage: Iusti Coniuges from the Time of Cicero to the Time of Ulpian (Oxford: 1991).

Von Moos P., "Das Öffentliche und Private im Mittelalter: Für einen kontrollierten Anachronismus", in Melville G. - von Moos P. (eds.), Das Öffentliche und Private in der Vormoderne (Cologne - Weimar - Vienna: 1998) 3-83.

Wacks R., Personal Information: Privacy and the Law (Oxford: 1989).

Warren S.D. - Brandeis L.D., "The Right to Privacy", Harvard Law Review 4.5 (189o) 193-220.

Webb D., Privacy and Solitude in the Middle Ages (London - New York: 2007). 